\title{
Issue of COVID-19 in Air Transport Industry
}

\author{
Mahdi Gholami \\ Aerospace Research Institute, Ministry of Science, Research, and Technology, Tehran, Iran
}

\section{Email address:}

gholami@ari.ac.ir

\section{To cite this article:}

Mahdi Gholami. Issue of COVID-19 in Air Transport Industry. American Journal of Mechanical and Industrial Engineering.

Vol. 6, No. 3, 2021, pp. 39-42. doi: 10.11648/j.ajmie.20210603.12

Received: June 30, 2021; Accepted: August 3, 2021; Published: August 24, 2021

\begin{abstract}
This article provides an overview of the global air transport challenge in response to the COVID-19 crisis. Companies and airlines around the world have had a difficult year. The Coronavirus pandemic and restrictions on people moving between countries and cities have reduced the number of flights to a minimum. In general, aviation creates opportunities for businesses and individuals, and in return can create dangers and threats to society. In particular, the spread of infectious diseases or pandemics - such that aviation can act as a channel of disease transmission- or the effect of aviation on global warming are two clear examples of the negative external effects of the aviation industry on society that need to be addressed. In this regard, the economic performance of the industry is very important. In analyzing the transportation industry, one should pay special attention to possible, reasonable, and desirable scenarios. Hence, protectionist policies, government assistance, and other industrial strategies can be reviewed. The policy review of government actions in the face of the challenges of the aviation industry emphasizes the importance of designing reasonable scenarios for sustainable development and the greater welfare of communities. Eliminating or reducing the prevalence of coronavirus and lifting restrictions on a variety of businesses, including airlines, can help improve corporate status. This situation will also enable companies to compensate for past losses in the coming year, in addition to improving services.
\end{abstract}

Keywords: Air Transport, Challenges, COVID-19, Vulnerability, Government Aid

\section{Introduction}

Just as a national or regional economy is severely affected by the spread of infectious diseases, some sectors of the economy will be more affected by such epidemics and pandemics than others. One of the first and most important of these sectors is the field of transportation and tourism in general and the aviation sector in particular. For example, Rassy and Smith [20] examined the negative economic effects of the H1N1 Influenza outbreak on the Mexican tourism sector by examining the number of international tourists arriving in Mexico in 2012. The two findings show that Mexico lost about 1 million tourists, which caused about $\$ 2.8$ billion in damage to the Mexican tourism industry.

In a similar study, Joo et al. [16] examined the negative economic effects of the MERS-CoV outbreak on South Korea's tourism-related industries. The results also show a 2.1 million drop in tourists and a \$ 2.6 billion loss to South Korea's tourism-related sectors. Another example is the article by Browne and Smith [4]. They estimate the financial losses inflicted on the domestic tourism sectors of China and Malaysia as a result of the outbreak of acute respiratory syndrome (SARS) at about $\$ 3.5$ billion and $\$ 1.7$ billion, respectively.

The state of the Corona epidemic has led to a change in the global landscape of tourism, as well as the paralysis of the air fleets of many countries around the world. In particular, according to International Air Transportation Association (IATA), air transport in May and April 2020, compared to the same time in 2019, decreased by about $15 \%$ [14], This unprecedented decline has had a major impact on the entire aviation industry value chain, including aircraft manufacturers, airlines, airports, as well as related sectors such as food services and retail. According to the World Tourism Organization, $58 \%$ of tourist arrivals are made by air transport, which has been severely affected by COVID-19 disease [26]. In fact, the consequences of the Coronavirus epidemic have had a very negative impact on the level of 
employment in tourism and tourism-related businesses in general. Therefore, and as the documents of the International Civil Aviation Organization (ICAO) pointed out, to stabilize and help the aviation industry value chain, billions of dollars have been allocated by governments to companies and institutions operating in the industry in the hope that companies can continue their day-to-day operations [15].

However, the forthcoming crisis is also reminiscent of the enduring challenges facing the global aviation industry. For example, the growing impact of aviation on global warming [6], the low and often negative profit margins of the aviation industry [10], and the aviation industry's continued reliance on government support [11] are issues that need to be addressed more closely. They noticed. On the other hand, the air transport system can have risks such as the spread of pathogens worldwide in a very short time [4]. In this regard, this article tries to use the current crisis to provide an overview of reform policies in the global transport system. This study is important in that we are currently witnessing large subsidies to the aviation sector to reduce economic vulnerability and increase environmental sustainability.

\section{COVID-19 and the Aviation Industry}

Numerous media reports and news indicate that the aviation industry is one of the victims of the COVID-19 epidemic in the world and the return of the industry to its normal state is of great importance for global trade and tourism [15]. However, the aviation industry itself will carry significant vulnerabilities, as it can spread pathogens. Examples include the transmission of malaria [29], or the global outbreak of HIV [7], or the spread of the SARS and MERS virus [8]. Air transport due to the presence of closed spaces such as airports and airplanes, as well as the density of population in such spaces, increases the likelihood of transmission of respiratory pathogens between individuals [4]. This issue becomes very important when it spreads globally. Because the spread of infectious diseases, in turn, has various costs such as prevention, research, treatment, loss of business opportunities, and ultimately recession.

Another industry challenge is the issue of global warming, which affects the aviation industry by creating high levels of pollution. Statistically, the calculations of the International Energy Agency (IEA) the amount of carbon dioxide emissions by the aviation sector until 2019 was about 1 gigaton per year [12]. Besides, The Intergovernmental Panel on Climate Change (IPCC) asserted that the impact of the aviation industry on global warming has increased due to the phenomenon of radiative forcing due to short-term radiation at flight altitudes [13]. Also, the current growing situation and predictions that the global aviation fleet will double in the next 20 years, highlights the importance of the aviation industry as one of the effective industries in the phenomenon of global warming $[3,19]$.

However, although such challenges have been well identified, they have not received much attention from relevant institutions and organizations. In particular, the prevalence and spread of pathogens is a costly factor in transportation and should be considered in the cost-benefit analysis of the industry. This issue should be considered when the relevant threats generally refer to the inductive benefits of the aviation industry [1].

Since such risks generally do not manifest themselves in financial statements, prices, and other economically justified costs, such global risks must also be addressed systematically. In fact, issues such as global warming and the spread of epidemics are examples of market failures and policies to impose socioeconomic costs on society. In this regard, we can refer to government assistance and subsidies in various forms such as lending, low-interest loans, tax exemptions, etc. by government and public organizations to infrastructure suppliers and airlines [5]. However, the question remains whether such government assistance, especially in times of crisis, has yielded overall positive results.

Understanding the dangers that the aviation industry poses to individuals (health and well-being of individuals) and communities (such as global warming and the spread of infectious diseases) has generally received little attention among policymakers and industry activists. Of course, the recent emergence of the COVID-19 has led to the growing challenge of the aviation industry in the spread of disease.

\section{Capacity of the Aviation Industry}

Today, there is ample evidence that reducing the real cost of aviation has many negative side effects through economic vulnerability to communities [11]. Reducing airfares will increase traffic and restructure international transport flows. For example, the share of international tourists transported by air has increased from $44 \%$ in 1998 to $58 \%$ in 2019 [27, 28]. At the same time, air passenger traffic has increased from 1.5 billion to 4.2 billion per year [23].

However, some evidence suggests that aviation is not one of the needs of all people. In fact, the importance of air transport for different income groups of people is not the same and there is a weak correlation between air transport demand and air transport needs. [9]

In response to these considerations, the industry's response has generally been the same as asking for more government assistance and doing the usual things, and in fact, there has been no need to change business models. For example, shifting the business model from revenue to profitability can both eliminate redundancies and increase industry profit margins. Such changes in the supply side also show themselves on the demand side with changes in prices and other parameters and will cause significant risks of global warming and reduce the prevalence of infectious diseases.

\section{Considerations on Industry Vulnerabilities}

The challenges raised in the previous sections highlight the 
importance of a more comprehensive and holistic view of the global aviation industry. Also, past crises, such as the financial crisis of 2008, show that it is good to return to its previous state. The International Transport Association (2020) predicts that although the COVID-19 crisis is longer and more stable, the aviation industry will return to normal in the medium term [14]. But the question is whether from a socio-economic point of view, this path is desirable or not? Because the evidence shows that, first, aviation can have significant "negative externalities" on society. Second, the demand for air transport is largely inductive and can shift in response to relatively low transport prices. Third, the industry's overall strategy is still focused on growing the amount and number of shipments rather than growing the industry's profit margin. Hence, the future vulnerabilities of the industry are becoming more and more apparent.

Well-known international consulting firms such as McKinsey have stated that the COVID-19 crisis bears many similarities to other crises, such as the global warming crisis. Thus, the risk of global warming is a systematic, unstable, nonlinear, and long-term risk that results from market failures [18]. In this regard, we can point to some results of the development of government assistance to the value chain of the aviation industry. In particular, aircraft companies, airlines, and airports, in general, have now received substantial, unconditional assistance from governments. According to a report by Market Watch from the Greenpeace Institute, about $€ 12.9$ billion in "government grants" have so far been awarded to European companies in Europe, and another $€ 17.1$ billion is being negotiated [24]. Similarly, in the United States, \$ 25 billion has been allocated to passenger airlines in the form of grants and loans. $\$ 8$ billion has also been awarded to freight airlines, and $\$ 3$ billion to airport contractors [21]. In Singapore, about $\$ 13$ billion has been donated to the country's airlines [22]. At the end of May 2020, the total amount of government aid exceeded $\$ 100$ billion, which is equivalent to almost half of the amount that the airlines received in the nine years from 2010 to 2018 [12]. In other words, the government assistance that has been provided so far to support the industry and the airlines are equivalent to the benefits that can be obtained over many years in the absence of other issues and problems, without considering the cost of its negative externalities.

\section{Conclusion}

Banister and Hickman state that in the transportation industry, reflection on complex and complex issues is one of the important policy issues [2]. This means that in analyzing the transportation industry, one should pay special attention to possible, reasonable, and desirable scenarios. In fact, it can be understood that so far, possible scenarios in the aviation industry have been generally addressed and reasonable and desirable scenarios have not received much attention. Possible scenarios are often developed in a purely economic framework to increase the volume of air travel, and in fact, no attention has been paid to other methods and routes of development of the aviation industry that leave fewer challenges. However, many activists and policymakers today have focused on leading the industry to environmental sustainability and greater financial flexibility. It seems that to achieve these issues, significant changes must be made in measuring the economic performance of the industry, technological advances, and the limits and limits of sustainable development of the growing global transportation system [10].

Overall, it can be acknowledged that there is still an inherent contradiction between reducing the risks, challenges, and vulnerabilities of the industry as well as the growth and expansion of the aviation industry. Therefore, a paradigm shift is needed to make it possible to limit the international aviation system while making it more desirable to society. In this regard, the COVID-19 crisis has forced many airlines to reduce their fleets, retire their old aircraft, or stop their long flights. For example, airlines such as Flybay, South African Airlines, and Eurowings have gone bankrupt, and airlines such as Virgin Australia or Irmoris have been given management powers as a result of bankruptcy [25]. As a result, air transport capacity has been reduced. Air transport capacity will also be reduced by reducing subsidies.

A plausible scenario for the aviation industry should begin with the question of how much air transportation is needed. The crisis of the COVID-19 must be considered here in particular. In fact, in the favorable scenario of the aviation industry, risks and dangers such as infectious diseases (corona) should be considered and the cost of such risks should be reflected in the final price of their air travel. In this situation, which may be justified by the reduction of supply, airlines should increase their profitability. Thus, COVID-19 provides an opportunity for companies, organizations, and institutions to review the global aviation industry. Indeed, the risks and harms that industry may inflict on society, and individuals should be weighed against the short-term benefits that the aviation industry receives as a result of increased travel volume. Hence, protectionist policies, government assistance, and other industrial strategies can be reviewed. Finally, the lesson that the Corona crisis teaches the national government, in addition to the potential and actual threats of the disease itself, enables them to act more accurately and effectively in crisis prevention and response policies.

\section{Conflict of Interest}

The authors declare that they have no competing interests.

\section{References}

[1] AviationBenefts, 2020. "Adding value to the economy". Online Available at: https://aviationbenefts.org/economicgrowth/adding-value-to-the-economy/

[2] Banister, D., Hickman, R., 2013. "Transport futures: thinking the unthinkable”. Transport Pol. 29, 283-293. 2013. 
[3] Boeing, 2019. "Commercial Market Outlook 2019-2038", Online Available at: https://www.boeing.com/commercial/market/commercialmarket-outlook/

[4] Browne, A., St-Onge Ahmad, S., Beck, C. R., Nguyen-VanTam, J. S. 2016. "The roles of transportation and transportation hubs in the propagation of influenza and COVID-19es: a systematic review”. J. Trav. Med. 23 (1), tav002.

[5] Doganis, R., 2005. "The Airline Business", second edition. Routledge, London.

[6] Fahey, D. W., Lee, D. S. 2016. "Aviation and climate change: a scientific perspective". Carbon Clim. Law Rev. (2), 97-104.

[7] Flahault, A., Valleron, A. J. 1992. "A method for assessing the global spread of HIV-1 infection based on air travel". Math. Popul. Stud. 3 (3), 161-171.

[8] Gardner, L. M., Chughtai, A. A., MacIntyre, C. R. 2016. "Risk of global spread of Middle East respiratory syndrome COVID-19 (MERS-CoV) via the air transport network". J. Trav. Med. 23 (6), taw063.

[9] Gossling, “ S., Hanna, P., Higham, J., Cohen, S., Hopkins, D. 2019. "Can we fly less? Evaluating the 'necessity' of air travel". J. Air Transport. Manag. 81.

[10] Gossling, S., Higham, J. 2020. "The low carbon imperative: destination management under urgent climate change". J. Trav. Res. Online Available at: https://doi.org/10.1177/ 0047287520933679

[11] Gossling, S., Fichert, F., Forsyth, P. 2017. "Subsidies in aviation”. Sustainability 9 (8), 1295.

[12] IEA, 2019. "Oil Information 2019". Online Available at: https://www.iea.org/reports/oil-informatio n-2019.

[13] IPCC (Intergovernmental Panel on Climate Change), 1999. "Aviation and the global atmosphere", A special report of IPCC working groups I and III. In: Penner, J. E., Lister, D. H., Griggs, D. J., Dokken, D. J., McFarland, M. (Eds.), Special Report of the Intergovernmental Panel on Climate Change. Cambridge University Press, Cambridge.

[14] IATA, 2020. "May Passenger Demand Shows Slight Improvement". IATA. Online Available at: https://www.iata.org/en/pressroom/pr/2020-07-01-02/.

[15] ICAO, 2020. "Effects of Novel COVID-19 on Civil Aviation: Economic Impact Analysis" 8 May 2020. Online Available at: https://www.icao.int/sustainability/Documents/COVID19/ICA O_COVID-19_Econ_Impact.pdf

[16] Joo H, Maskery BA, Berro AD, Rotz LD, Lee YK, Brown CM. 2019. Economic Impact of the 2015 MERS Outbreak on the Republic of Korea's Tourism-Related Industries. Health Security. Mar/Apr; 17 (2): 100-108.
[17] Keogh-Brown, M. R., \& Smith, R. D. 2008. The economic impact of SARS: how does the reality match the predictions? Health policy (Amsterdam, Netherlands), 88 (1), 110-120. https://doi.org/10.1016/j.healthpol.2008.03.003

[18] McKinsey \& Company, 2020. "How airlines can chart a path to zero-carbon flying". Online Available at: http://www.mckinsey.com/industries/travel-transport-andlogisti cs/our-insights/how-airlines-can-chart-a-path-to-zerocarbon-flying?cid=eml-web.

[19] Peeters, P., Higham, J., Kutzner, D., Cohen, S., Gossling, S. 2016. "Are technology myths stalling aviation climate policy?”, Transport. Res. Transport Environ. 44, 30-42.

[20] Rassy, D. and Smith, R. D. 2013, The economic impact of H1N1 on Mexico's tourist and pork sectors. Health Econ., 22: 824-834. doi: $10.1002 /$ hec. 2862 .

[21] Reuters, 2020a. "U.S. Senate approves big rescue for struggling aviation sector". Online Available at: https://www.reuters.com/article/us-health-COVID-19-usabill/u-s-senate-approves

[22] Reuters, 2020b. "Singapore Airlines latest to get massive rescue amid COVID-19 crisis". Online Available at: https://www.reuters.com/article/us-health-COVID-19-airlinesidUS KBN21D3UW

[23] The World Bank, 2020. "Air transport, passengers carried". Online Available at: https://data.worldbank.org/indicator/IS.AIR.PSGR

[24] T\&E, Greenpeace, Carbon Market Watch, 2020. "Airline Bailout Tracker". Online Available at: https://www.transportenvironment.org/sites/te/files/Airlinebailout-tracker_8_May_2020.pdf

[25] TTRWeekly, 2020. "Global aviation now in crisis". Online Available at: https://www.ttrweekly. com/site/2020/05/globalaviation-now-in-crisis/

[26] UNWTO, 2019. "International Tourism Highlights". World Tourism Organization. Online Available at: https://www.eunwto.org/doi/pdf/10.18111/9789284421152.

[27] UNWTO, 2000. "UNWTO Tourism Highlights", 2000 Edition. Online Available at: https://www.eunwto.org/doi/pdf/10.18111/9789284403745

[28] UNWTO, 2020. "Global and Regional Tourism Performance". Mode of Transport World 2018. Online Available at: https://www.unwto.org/global-and-regional-tourismperformance.

[29] Wieters, I., Eisermann, P., Borgans, F., Giesbrecht, K., Goetsch, U., Just-Nübling, G. 2019. "Two cases of airportassociated falciparum malaria in Frankfurt am Main, Germany", Euro Surveill. 24 (49). 